\title{
Evaluation of The Efficacy of Diode Laser, Chlorhexidine Digluconate Gel and Calcium Hydroxide Paste In The Disinfection Of Candida Albicans Infected Root Canals, In Vitro Study Faisal Tameem Al Jadir \\ M.Sc.D
}

\begin{abstract}
the study aims to evaluate the efficacy of $\mathrm{CHX}$-gel, $\mathrm{Ca}(\mathrm{OH})_{2}$ and diode laser in eliminating C.albicans from the root canal system and hence to eliminate the chances of reinfection and minimize treatment time.

Materials and methods: 180 single rooted anterior teeth were prepared and divided into 4 equal groups, the first was prepared to ISO 60 while the $2^{\text {nd }}-4^{\text {th }}$ were prepared only to ISO40, all the teeth were then sterilized and inoculated with C.albicans suspensions for 14 days, followed by evaluation of the starting bacterial counts in each tooth by means of colony forming units (CFU/ml), after this the groups 2-4 were prepared to ISO $40 \mathrm{MAF}$, using $\mathrm{NaCl} 9 \%$ in the $2^{\text {nd }}$ group, $\mathrm{NaOCl} 1 \%$ in the $3^{\text {rd }}$ and $\mathrm{CHX} 0.2 \%$ in the $4^{\text {th }}$. Finally each of the 4 groups was divided into three subgroups $(n=20)$, the first irradiated with diode laser, the second with injected with $\mathrm{Ca}(\mathrm{OH})_{2}$ paste and the third injected with $\mathrm{CHX}$-gel for 7 days, followed by estimation of the end bacterial counts in CFU/ml in canal lumen and in dentin.
\end{abstract}

Results : the reduction of C.albicans was higher in all the groups after $\mathrm{Ca}(\mathrm{OH})_{2}$ and $\mathrm{CHX}$ gel injection than with diode laser irradiation ( $p<0.001$, Chi-square test). After chemomechanical preparation a higher effectivity of the laser disinfection was shown and more specimen could reach the lower limit values, the effectiveness was also increased by the use of $\mathrm{NaOCl}$ or $\mathrm{CHX}$ as irrigants $(p<0.001)$.

\section{INTRODUCTION:}

A preliminary condition for successful root canal therapy is the reduction of microorganisms before filling of the root canals ( Sjogren et al. 1997, Sundqvist et al. 1998), in spite of the reduction achieved by the chemomechanical preparation and the utilization of intracanal medicaments, some microorganisms stay in the irregularities of the canals and the dentinal tubules (Peters et al. 2000) which can be a reason for minimizing success rates and reinfection (Sjogren et al. 1997) this is not only caused by individual failures but by existence of resistant bacterial species (Sundqvist 1994), usually the primary endodontic infections are associated with a mixed anaerobic population, while secondary infections are mostly caused by enterococci species or candida albicans (Waltimo et al.1997, Sundqvist et al. 1998, Pinheiro et al. 2003), the effectivity of the classic calcium hydroxide against these species has been found limited (Waltimo et al. 1999, Siqueira et al. 2004, Siren et al. 2004), thus many alternatives have been tried to optimize the disinfection of the root canal system and to enable a one session therapy. Laser light have antimicrobial properties and can achieve an effective microbial reduction in vivo (Moritz et al. 1997), till now little evidence based studies have focused on their effect in achieving effective one session therapy.

The aim of our study is to find the effectivity of laser application in comparison with the use of $\mathrm{Ca}(\mathrm{OH})_{2}$ and $\mathrm{CHX}$-gel in the reduction of $\mathrm{C}$. albicans from the root canal system.

\section{MATERIALS AND METHODS \\ Study design}

As a part of our study three types of treatment were carried on, which required classifying the teeth into three subgroups, in the first subgroup diode laser application was done (GENTLEray 980, Kavo, Germany), in the second a 7 day intracanal medication of Calcium hydroxide paste (UltraCal XS, Ultradent, USA) was injected and in the third subgroup a 7 day intracanal medication of CHX (Chlorhexamed, 1\% gel, Galaxosmithcline ) was injected.

Every one of these treatments was examined alone and in combination with the other therapy methods which included mechanical preparation/ no preparation conditions and $\mathrm{NaCl}$ or $\mathrm{NaOCl}$ or $\mathrm{CHX}$ irrigation conditions, a total of 12 study groups were built, each study group had a total probe count of 15 specimen, so a total of 180 probes was examined.

Table.1. description of the study groups:
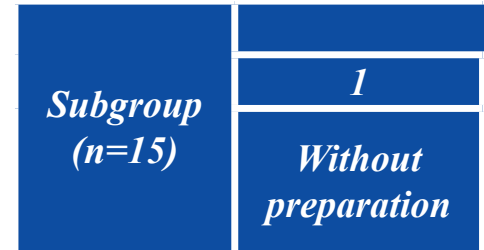

Without
preparation

\section{1}

1.2

1.3

\section{Main group $(n=60)$}

\begin{tabular}{|c|}
\hline 2 \\
\hline Preparation \\
with $\mathrm{NaCl}$ \\
irrigation
\end{tabular}

\begin{tabular}{|c|}
\hline \\
\hline Preparation \\
with $\mathrm{NaOCl}$ \\
irrigation
\end{tabular}

2.1

2.2

2.3

\begin{tabular}{|c|}
\hline 4 \\
\hline Preparation \\
with CHX \\
irrigation
\end{tabular}

4.1

4.2

4.3 
n: number of teeth (probes).

Before beginning of the study sequence a the main group3 with sodium hypochlorite $(\mathrm{NaOCl}$ complete preparation of the specimens of main $1 \%$ ) and with $\mathrm{CHX}$-gel $0.2 \%$ in the $4^{\text {th }}$ main group. group 1 was done to ISO 60(MAF) while in the The subgroups 3 and 4 served as positive controls, groups 2-4 initial preparation to ISO 40 was done the negative controls were the bacterial counts of $1^{\text {st }}$ (MAF), the complete preparation of the canals in subgroup, the following table describes in details the these groups was done during the study, in the main study procedures: group 2 with physiologic normal saline $(\mathrm{NaCl} 1 \%)$, in

Table.2; description of the study procedure.

\begin{tabular}{|c|c|c|c|}
\hline Main groupl & Main group 2 & Main group 3 & Main group 4 \\
\hline \multicolumn{4}{|c|}{$\begin{array}{c}\text { Irrigation and dryness } \\
\text { Sterilization } \\
\text { Placement in tubes }\end{array}$} \\
\hline $\begin{array}{l}\text { Preparation to ISO } 60 \\
\mathrm{NaCl} \text { irrigation }\end{array}$ & \multicolumn{3}{|c|}{$\begin{array}{c}\text { Preparation to ISO } 40 \\
\mathrm{NaCl} \text { irrigation }\end{array}$} \\
\hline \multicolumn{4}{|c|}{$\begin{array}{l}\text { Sterilisation } \\
\text { Implantation of C.albicans } \\
\text { Incubation }\end{array}$} \\
\hline \multicolumn{4}{|c|}{$\begin{array}{l}\text { Starting bacterial count } \\
\text { (CFU/ml) }\end{array}$} \\
\hline \multirow{2}{*}{ No further preparation } & \multicolumn{3}{|c|}{ Further preparation to ISO 60} \\
\hline & $\mathrm{NaCl}$ irrigation & $\mathrm{NaOCl}$ irrigation & CHX irrigation \\
\hline 1.1 & 2.1 & 3.1 & 4.1 \\
\hline 1.2 & 2.2 & 3.2 & 4.2 \\
\hline 1.3 & 2.3 & 3.3 & 4.3 \\
\hline \multicolumn{4}{|c|}{$\begin{array}{l}\text { End bacterial count } 1(\mathrm{CFU} / \mathrm{ml}) \\
\text { End bacterial count } 2(\mathrm{CFU} / \mathrm{mg} \text { Dentin })\end{array}$} \\
\hline
\end{tabular}

\section{Preparation of the specimens:}

A total of 180 single rooted extracted teeth were collected, after full debridement with ultrasound endo tips (SONICFlex, Kavo), they were sterilized with ethylene oxide and the crowns cut with diamond burs and all the specimen were brought to a length of a $19 \mathrm{~mm}$, Fig.1,

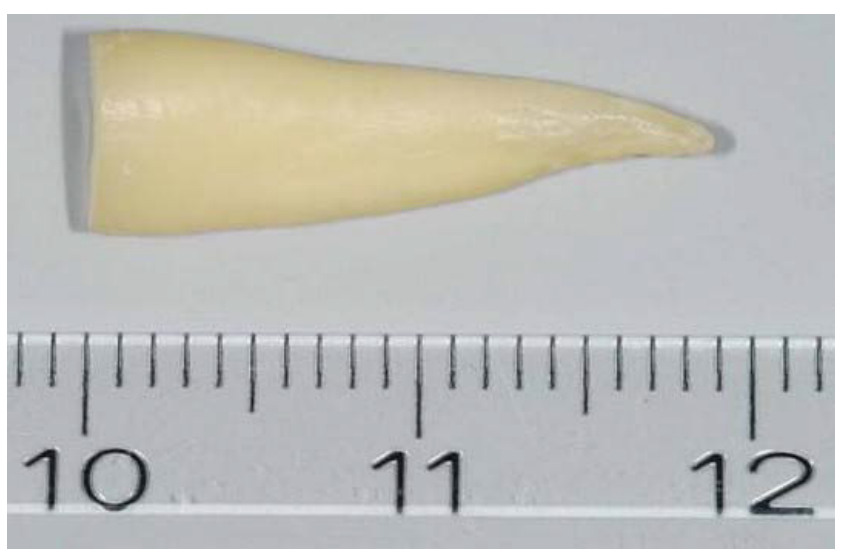

Fig.1; root length determination.

During the period of preparation the samples were kept in physiological normal saline and the preparation of all teeth was unified to a length of 18 $\mathrm{mm}$. Specimen of the first main group were prepared to ISO 60 and of the other groups to ISO 40 as listed above (Flexmaster System VDW), during the preparation debris were removed using normal saline ( $\mathrm{NaCl} 0.9 \%)$ and EDTA (FileEze, Ultradent) was used to wash away the smear layer. To ensure a unified preparation depth, composite stoppers were designed on the files, and the orifices of the canals were assured to be cone shaped using $2.9 \mathrm{~mm} \varnothing$, orifice former diamond (Riitano access bur kit, Ultradent, USA). To ensure ease of access. After preparation each of the specimen were kept in sterile normal saline containers for 14 days and the solution was changed everyday. After preparation the teeth were painted with nail polish followed by embedding in fast setting resin, Fig.2, 


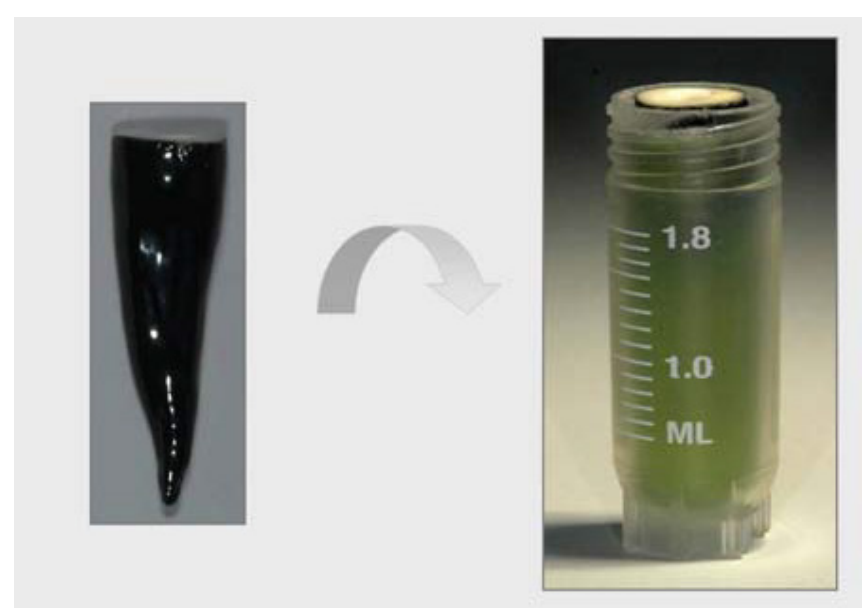

Fig.2; nail polish painting and embedding of specimen.

To ensure sterilization ten specimen were selected randomly and injected with universal nutrition solution ( Tryptone Soya broth) and incubated for 14 days at $37^{\circ} \mathrm{C}$ the resulting solution was then implanted over columbia agar with sheep blood and incubated for $24 \mathrm{hrs}$ at $37^{\circ} \mathrm{C}$. after proving the sterility a $30 \mu \mathrm{l}$ suspension of C.albicans in Sabouraud Dextrose solution injected in the canals of all the teeth in the specimen, the starting concentration was $10^{5} \mathrm{CFU} / \mathrm{ml}$, the specimen was incubated for 14 days at $37^{\circ} \mathrm{C}$ and a sterile nutritive medium was daily given (Sabouraud liquid medium, Oxoid), the cover of the embedding tubes was kept loose. Before beginning of the main experiment To obtain the intracanal bacterial count , $5 \mu 1$ of the solution was drawn with paper points and with a dilution of 1:4000000 implanted, after an incubation for $24 \mathrm{hrs}$ at $37^{\circ} \mathrm{C}$, the resulting colonies were counted and the count of microorganisms in the canal per $\mathrm{ml}$ of liquid (CFU/ml) against the dilution factor was calculated.

To be able to calculate the exact bacterial count pro milliliter of solution in the canal we need to know the exact volume of fluid taken by the paper point and hence to evaluate this, paper points (ISO 40 VWD) were immersed in previously pipetted volumes of 5,10 and $15 \mu \mathrm{l}$ of liquid to the depth of $18 \mathrm{~mm}$. we found that an average paper point can fully absorb up to $5 \mu \mathrm{l}$ of the solution. To reach the dilution value , paper points were immersed in sealable tubes with $1,995 \mathrm{ml}$ normal saline, the tubes were placed in vortex mixer for 30 seconds, from this solution $10 \mu 1$ were pipetted and placed in $0.99 \mathrm{ml}$ sterile normal saline tubes then vortexed for $30 \mathrm{~s}, 10 \mu 1$ were pipetted from this solution and implanted in (Sabouraud-GlucoseHefeextract selective media, Oxoid) and so a dilution of 1:4000000 was reached which enables us to find the exact bacterial count pro $\mathrm{ml}$.

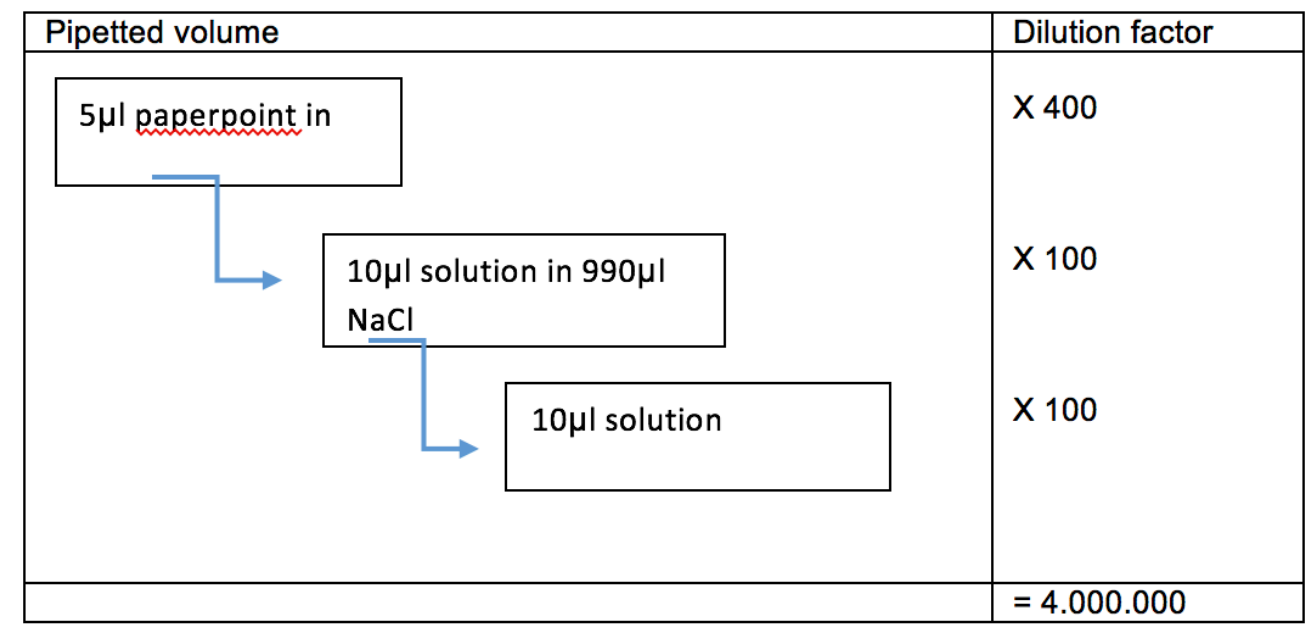

Calculation of bacterial count was done on a selective media for fungi (Sabouraud- GlucoseHefeextract selective media, oxoid), in addition three specimen from each subgroup were examined for contamination on universal nutritive media (Columbia agar with sheep blood, oxoid) during the start and the end bacterial count procedures.

\section{Procedure:}

Immediately after calculation of the starting bacterial count, the experimental procedure started with the preparation of the specimen of groups 2-4 to ISO 60 with $9 \% \mathrm{NaCl}$ in group 2 and with $1 \% \mathrm{NaOCl}$ in group 3 and with $0.2 \% \mathrm{CHX}$ in the $4^{\text {th }}$ group. Candida solution was washed with $2 \mathrm{ml} 9 \% \mathrm{NaCl}$ and each canal was dried with 3 paper points ISO 40, corresponding to their classification in subgroups, the specimen were treated after that as follows:

The first subgroup was irradiated with diode laser (Epic, Biolase, USA) with maximum output power of $7 \mathrm{~W}, 200 \mu \mathrm{m}$ fiber, inserted into $17 \mathrm{~mm}$ length, the fiber was inserted in spiral movement along the canal wall in $3 \mathrm{~mm} / \mathrm{s}$ for 10 s from apical to coronal, Fig.3; 


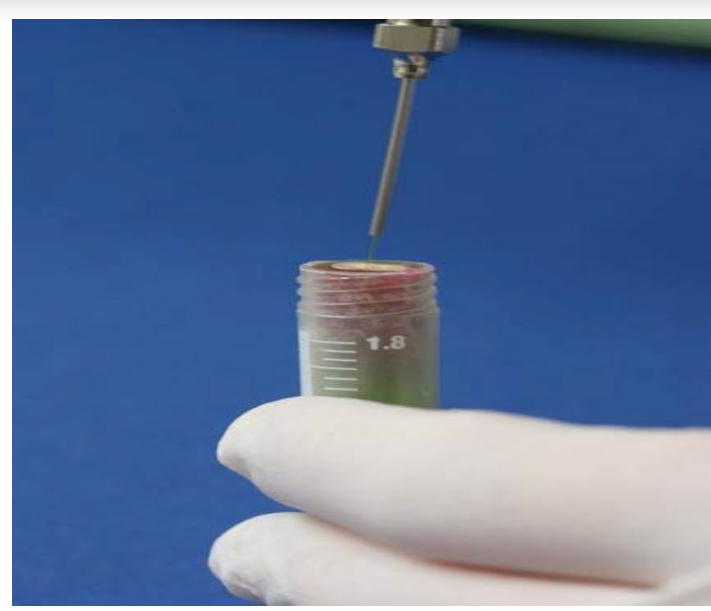

Fig.3; laser application procedure.

In each canal the procedure was repeated 4 times for overall 40s.

In the $2^{\text {nd }}$ subgroup, chlorhexidine digluconate gel $(1 \%)$ was injected in the canals and they were incubated for 7 days, a disposable endo injection tip was used (NaviTip, Ultradent, USA) to inject the material slowly from apical to coronal to avoid airbubble formation and adequately fill the canal then canals were covered and incubated for 7 days at $37^{\circ} \mathrm{C}$. Similarly in the $3^{\text {rd }}$ subgroup the canals were injected with calcium hydroxide paste (UltraCal XS( $\mathrm{Ph} 12.5$ ), Ultradent, USA) with endo tips (NaviTip, Ultradent, USA) from apical to coronal in a slow movement then covered and incubated for 7 days at $37^{\circ} \mathrm{C}$.

To obtain the end bacterial count, all canals were washed with $2 \mathrm{ml} \mathrm{NaCl}(0.9 \%)$ solution. In the first subgroup this was done after laser irradiation while in the $2^{\text {nd }}$ and $3^{\text {rd }}$ subgroups after the incubation, then paper points (ISO 40) were used to take the bacterial specimen (CFU/ml) and Hedstrom files (ISO 40) were used to obtain dentinal specimen from the root canal wall (CFU/mg).

\section{Evaluation of the end bacterial count:}

a.End bacterial count of the canal :

Because of the previously investigated C.albicans growth sequence in literature, the dilution factor and the starting average bacterial count could be evaluated so that an average bacterial count of $10^{8} \mathrm{CFU} / \mathrm{ml}$ could be accepted and the dilution factor of 1:4000000 was considered (Sen et al. 1999-2000, Valera et al. 2001, Ferguson et al. 2002, Siqueira et al. 2003, Menezes et al. 2004, Brandle et al. 2008) . For the end count this was not possible since we have no expected value for the $\mathrm{CFU} / \mathrm{ml}$. In case we consider a smaller dilution factor so the result is higher number of colonies $>1000$ which are difficult to count and their growth behavior is limited on the media, a smaller dilution however gives the possibility to lower the lowest confirmed bacterial count to $5 \times 10^{2} \mathrm{CFU} / \mathrm{ml}$, so to keep the lowest limit as small as $5 \times 10^{2}$ and to have the possibility to quantify specimen with higher bacterial concentrations, 2 dilution factors were produced and implanted so that any concentration from $5 \times 10^{2}$ to $10^{8}$ $\mathrm{CFU} / \mathrm{ml}$ could be quantified.

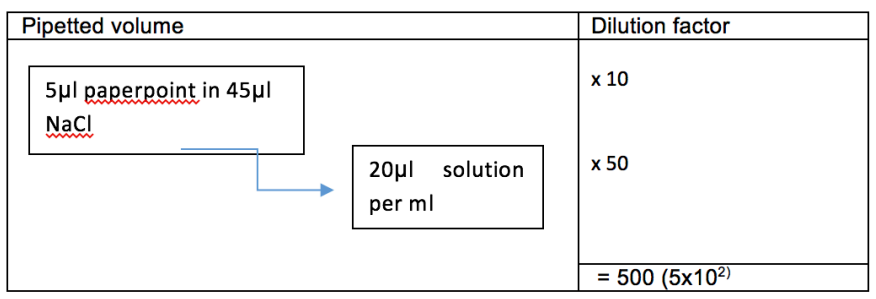

Dilution factor 1

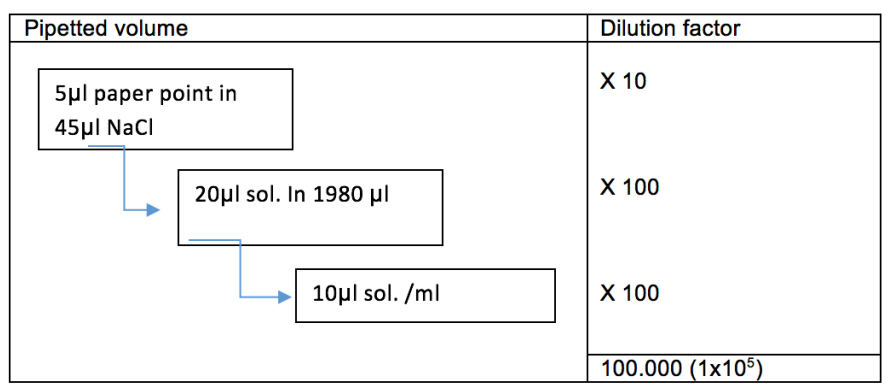

Dilution factor 2

b.Evaluation of the end bacterial count of the canal wall dentin:

ISO 40 Hedstrom file was inserted 3 times along the canal wall to obtain the dentinal specimen, files were then placed in sealable tubes (Safeseal Microtube $2 \mathrm{ml}$, Germany) with $50 \mu 1$ sterile normal saline and vortexed for 30 s then $20 \mu 1$ were pipetted and implanted on (Sabouraud-Glucose-Hefeextract, Oxoid) selective media. After an incubation for $24 \mathrm{hrs}$ at $37^{\circ} \mathrm{C}$ colonies were counted. First 10 files with and without dentin specimen were weighted and an average $0.0003 \mathrm{~g}$ specimen weight was obtained. Since $20 \mu 1$ were implanted so multiplying the counted colonies by 2.5 gives the bacterial count in $50 \mu 1$, this corresponds the count in a $0.0003 \mathrm{~g}$ specimen and the division on 0.3 gives the count per milligram (CFU/ $\mathrm{mg}$ ).

\section{Statistical analysis:}

For the quantitative evaluation, three variables were considered:

a.End bacterial count 1 (end bacterial count in canal) $\mathrm{CFU} / \mathrm{ml}$

b.End bacterial count 2 (end bacterial count in dentin) $\mathrm{CFU} / \mathrm{mg}$

Then all the values of the starting bacterial count were considered as baseline and tested with Kruskal- 
Wallis test for difference $(\mathrm{p}<=0.05)$. since the end bacterial count inside the same subgroup varied either below or above the limits, we built three classes for the end count values, the classes were (under the lower limit, middle value, high value), presence of these classes for all the 12 subgroups was summarized in cross tables and graphs were produced for each main group. The study groups were compared concerning the end bacterial count in canal and in dentin, each single treatment group against different preparations and different preparation against treatments were compared with Chi-square test, all the previous tests were carried out using SPSS software 16.0 (SPSS, Germany). 2 factor ordinal logistic regression analysis were carried out to evaluate the three levels of end bacterial count and the relative bacterial count reduction using the software SAS 9.1 (SAS Institute, USA). The start and end bacterial count in dentin was compared (Chi-Quadrat-test) and the presence of a relation between the end bacterial count in canal and in dentin was examined.

\section{RESULTS}

\section{Quantitative evaluation:}

Before starting the experimental work, a random specimen of the experimental teeth starting from $10^{5}$ $\mathrm{CFU} / \mathrm{ml}$, could reach a concentration of $10^{8} \mathrm{CFU} /$ $\mathrm{ml}$ after 14 days, in this power the concentration remained until 21 days, so the incubation period of C.albicans suspension was fixed on 14 days.

\section{Starting bacterial count:}

At the beginning of the procedure the starting count was estimated in all the canals, the median value was $3.66 \times 10^{8} \mathrm{CFU} / \mathrm{ml}$, where the lowest value was $8 \times 10^{6}$ and the highest $1.28 \times 10^{9} \mathrm{CFU} / \mathrm{ml}$. the starting count in dentin was estimated by selecting 4 more canals, implanting them with C.albicans and incubation for 14 days, the starting counts in the canals and in the dentinal wall were:

Table 4; starting bacterial counts in the canal and in the dentin of the selected specimen.

\begin{tabular}{c|c|c|}
\hline Specimen & Starting count in canal & $\begin{array}{c}\text { Starting count in } \\
\text { dentin }\end{array}$ \\
\hline 1 & $13,84 \times 10^{8} \mathrm{CFU} / \mathrm{ml}$ & $7,10 \times 10^{3} \mathrm{CFU} / \mathrm{mg}$ \\
2 & $22,04 \times 10^{8} \mathrm{CFU} / \mathrm{ml}$ & $1,02 \times 10^{5} \mathrm{CFU} / \mathrm{mg}$ \\
\hline 3 & $39,60 \times 10^{8} \mathrm{CFU} / \mathrm{ml}$ & $9,83 \times 10^{4} \mathrm{CFU} / \mathrm{mg}$ \\
4 & $42,56 \times 10^{8} \mathrm{CFU} / \mathrm{ml}$ & $6,80 \times 10^{4} \mathrm{CFU} / \mathrm{mg}$ \\
\hline Average & $4,51 \times 10^{8} \mathrm{CFU} / \mathrm{ml}$ & $8,48 \times 10^{4} \mathrm{CFU} / \mathrm{mg}$ \\
\hline
\end{tabular}

\section{End bacterial count 1:}

The end bacterial count was estimated in all the specimen and since the values varied but either were lower than a lower limit or higher than an upper limit, 3 classes of values were considered for statistical analysis.

\begin{tabular}{c|c}
\hline Lower than the lower limit & $<5 \times 102 \mathrm{CFU} / \mathrm{ml}$ \\
\hline Middle value & $5 \times 102-4 \times 103 \mathrm{CFU} / \mathrm{ml}$ \\
\hline High value & $>4 \times 103 \mathrm{CFU} / \mathrm{ml}$
\end{tabular}

Classification of the end bacterial counts in the value fields was done for all the specimen and the results were tested against one another (Chi square test, $\alpha=0.05$ ), to simplify the results, percentages ( of $100 \%$ ) of each value were clarified using bar charts for each main group:

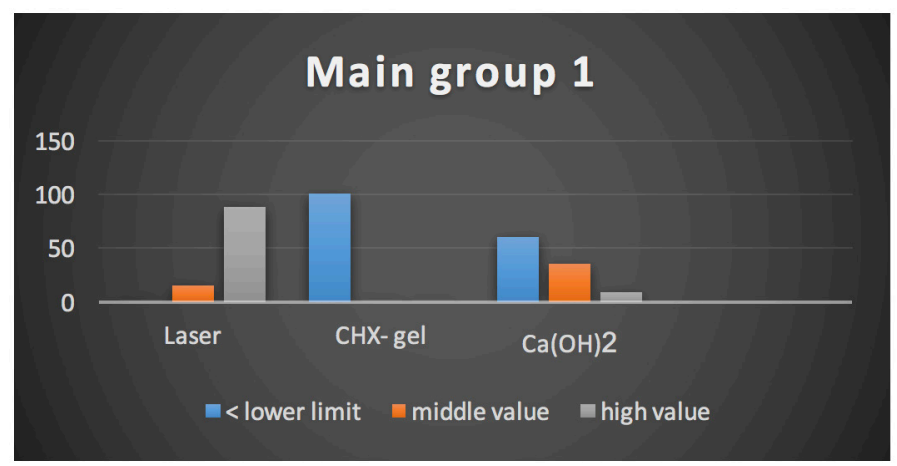

By the use of $\mathrm{Ca}(\mathrm{OH})_{2}, 60 \%$ of the cases were in the lower limit field and $33,3 \%$ were in the middle field, using diode laser no values were in the lower value field and $86,7 \%$ were in the high value field, the utilization of $\mathrm{Ca}(\mathrm{OH})_{2}$ had significant effect from the laser treatment $(p<0.001)$ and the use of CHXgel caused significant decrease more than $\mathrm{Ca}(\mathrm{OH})_{2}$, $(p=0.017)$ were all the specimen were in the lower value field.

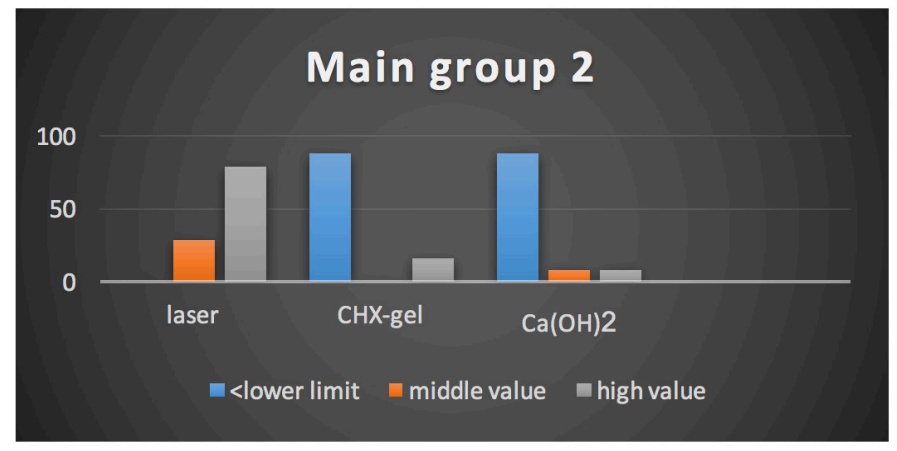

through the additional preparation and use of $\mathrm{NaCl}$ the effect was clear on having specimen with lower limit values for the laser and $\mathrm{Ca}(\mathrm{OH})_{2}$ groups, utilization of $\mathrm{Ca}(\mathrm{OH})_{2}$ and $\mathrm{CHX}$-gel did not differ significantly, both reached $86,7 \%$ bacterial count under the lower limit, while laser treatment did not have any counts below the lower limit.

Utilization of $\mathrm{NaOCl}$ as irrigant in group 3 , caused an increase in the number of teeth without C.albicans after laser and $\mathrm{Ca}(\mathrm{OH})_{2}$, only the laser 
group showed values higher than the high value. The combination of chemomechanical preparation and $\mathrm{NaOCl}$ irrigation together with $\mathrm{CHX}$-gel or $\mathrm{Ca}(\mathrm{OH})_{2}$ resulted in bacterial count reduction below the lower limit in all the treated teeth, however there was a significant difference between $\mathrm{CHX}$-gel and $\mathrm{Ca}(\mathrm{OH})_{2}$ from the laser therapy $(p=0.042)$.

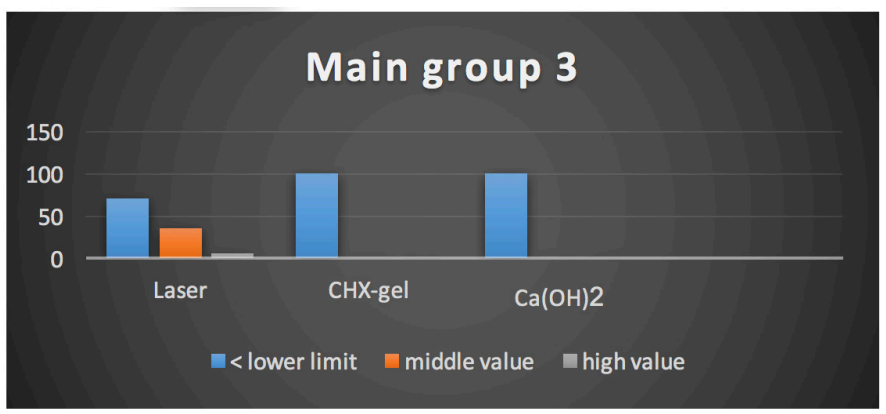

In group 4 the chemomechanical preparation with $\mathrm{CHX}$-irrigant resulted in more specimen in the subgroups of laser and $\mathrm{Ca}(\mathrm{OH})_{2}$ below the lower limit, this was clear for about $70 \%$ of the laser and $100 \%$ of $\mathrm{Ca}(\mathrm{OH})_{2}$ specimen.

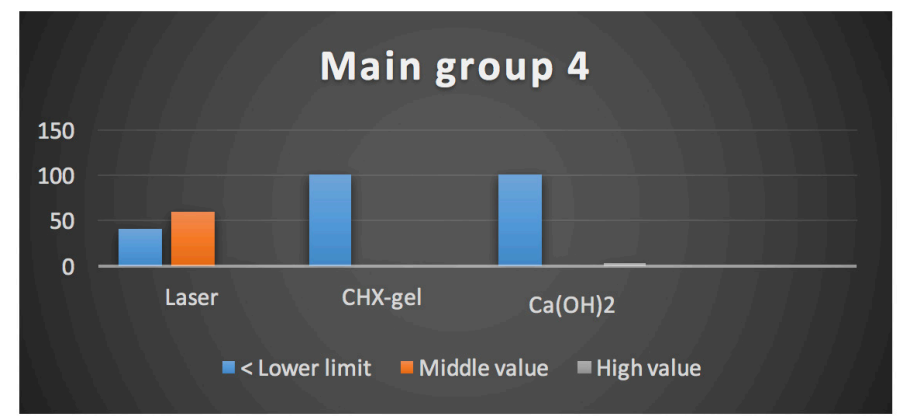

The results show that the lower limit values of $<5 \times 10^{2} \mathrm{CFU} / \mathrm{ml}$ could be $100 \%$ achieved through application of CHX gel without further preparation using $\mathrm{CHX}$ irrigant, $\mathrm{NaCl}$ or $\mathrm{NaOCl}$.

\section{End bacterial count 2:}

Since the values varied they were classified in three value fields according to the following tables:

Table.6. classification of the end bacterial count 2 values in main group 1;

\begin{tabular}{c|c|c|c|c|}
$\begin{array}{c}\text { No prepa- } \\
\text { ration }\end{array}$ & \multicolumn{4}{|c|}{ preparation } \\
\cline { 2 - 5 }$(\boldsymbol{C F U / m g})$ & Laser & $\begin{array}{c}\text { CHX- } \\
\text { gel }\end{array}$ & $\mathbf{C a}(\mathrm{OH})_{2}$ & Total \\
\hline $\begin{array}{c}<\text { lower } \\
\text { limit }\end{array}$ & 0 & 15 & 11 & 26 \\
\hline $8,33-4,999$ & 0 & 0 & 4 & 4 \\
\hline$>5000$ & 15 & 0 & 0 & 15 \\
\hline Total & 15 & 15 & 15 & 45 \\
\hline
\end{tabular}

Table.7. end bacterial count 2 values in main group 2;

\begin{tabular}{c|c|c|c|c|}
\hline $\begin{array}{c}\mathrm{NaCl} \\
(\mathrm{CFU} / \mathrm{mg})\end{array}$ & Laser & $\begin{array}{c}\text { PHX- } \\
\text { gel }\end{array}$ & $\mathbf{C a}(\mathbf{O H})_{2}$ & Total \\
\hline $\begin{array}{c}\text { < lower } \\
\text { limit }\end{array}$ & 0 & 15 & 13 & 28 \\
\hline $8,33-4,999$ & 1 & 0 & 2 & 3 \\
\hline$>5000$ & 14 & 0 & 0 & 14 \\
\hline Total & 15 & 15 & 15 & 45 \\
\hline
\end{tabular}

Table.8. end bacterial count 2 values in main group 3;

\begin{tabular}{c|c|c|c|c|}
\hline $\begin{array}{c}\text { NaOCl } \\
(\mathrm{CFU} / \mathrm{mg})\end{array}$ & Laser & $\begin{array}{c}\text { CHX- } \\
\text { gel }\end{array}$ & $\mathbf{C a}(\mathbf{O H})_{2}$ & Total \\
\hline $\begin{array}{c}<\text { lower } \\
\text { limit }\end{array}$ & 11 & 15 & 15 & 41 \\
\hline $8,33-4,999$ & 4 & 0 & 0 & 4 \\
\hline Total & 15 & 15 & 15 & \\
\hline
\end{tabular}

Table.9. end bacterial count 2 values in main group 4;

\begin{tabular}{c|c|c|c|c|}
$\begin{array}{c}\text { CHX } \\
\text { (CFU/mg) }\end{array}$ & Laser & $\begin{array}{c}\text { pHX- } \\
\text { gel }\end{array}$ & $\boldsymbol{C a}(\mathbf{O H})_{2}$ & Total \\
\hline $\begin{array}{c}<\text { lower } \\
\text { limit }\end{array}$ & 11 & 15 & 15 & 41 \\
\hline $8,33-4,999$ & 3 & 0 & 0 & 3 \\
\hline$>5000$ & 1 & 0 & 0 & 1 \\
\hline Total & 15 & 15 & 15 & 45 \\
\hline
\end{tabular}

\section{DISCUSSION}

We examined C.albicans in our research as one of the most causative factors of endodontic revisions (Siqueira et al.2004). After a standatdised procedure the starting situation could be unified in all the probes, the standard deviation $\left(2,728 \times 10^{8}\right)$ was due to difference in dentin morphology between the teeth and was considered biologically unnoticeable since the average value of all the probes had an exponent of $10^{8}$. The starting bacterial count in our specimen as average of $4,51 \times 10^{8} \mathrm{CFU} / \mathrm{ml}$ is near to that found as an average count of $4 \times 10^{5}$ in canals by Bystrom ( Bystrom et al. 1981) and that in dentin of $8,48 \times$ $10^{4} \mathrm{CFU} / \mathrm{mg}$ is somewhat lower than that found in infected canals by Peters $5 \times 10^{6}$ (Peters et al. 2001). The comparision of the end bacterial count 1 to the starting counts showed an indication for the treatment, in main group 1 the treatment with $\mathrm{CHX}$-gel was not significantly different from that of $\mathrm{Ca}(\mathrm{OH})_{2}, \alpha<=$ $\cdot, \cdots \leqslant r$, Chi square test) they both were significantly different from the laser group. More frequently there was a significant difference between the CHX-group 
and the laser group $(\mathrm{p}<0.001)$, the results were similar for $\mathrm{Ca}(\mathrm{OH})_{2}$ as the bacterial reduction was frequently higher than that of the laser group $(p<0.001)$. considering the bacterial count reduction in dentin the results were similar to the previous and the reduction was more by $\mathrm{CHX}$-gel then $\mathrm{Ca}(\mathrm{OH})_{2}$ then laser. The end bacterial counts of the free (canal) and adherent bacteria are highly related to this sequence as laser irradiation has not the same strong effect on biofilm bacteria as intracanal medicaments and in order to eliminate the chances of recurrent infection bacterial elimination is inevitable, however Peters reported that remaining microorganisms below the concentration of $10^{2} / \mathrm{ml}$ at the time of canal filling has no negative effect on the treatment outcome (Peters et al. 2002). According to our study this concentration could be $100 \%$ reached by the application of CHX-gel alone or in combination with preparation and irrigation with $\mathrm{NaOCl}$ or $\mathrm{CHX}$ solution, placing in mind the aim of manual or mechanical root canal preparation besides eliminating the necrotic and dentinal debris is to remove the bacterial attachments to the canal wall and provide a wider lumen for the action of intracanal medicaments but never to fully eliminate bacterial colonization's since many anatomical irregularities, ramifications and accessory canals cannot be reached (Orstavik et al. 1991), the concentration also could be reached after $\mathrm{Ca}(\mathrm{OH})_{2}$, application combined with chemomechanical preparation with $\mathrm{NaOCl}$ or $\mathrm{CHX}$ solution. The most effective treatment recommended according to our study is by the suggested intracanal medicaments with chemomechanical preparation with $\mathrm{NaOCl}$ or $\mathrm{CHX}$ solution. However we cannot give a clear recommendation to use the above treatments since our in vitro study is excluded from contamination factors and through the preparation and application of irrigants contamination may occur through oral microorganism or through the instruments themselves and this increases with the number of treatment sessions (Weiger et al. 2000), however our results are similar to those obtained by Ercan et al. whom investigated the effects of $2 \% \mathrm{CHX}$-gel on C.albicans and E.faecalis in comparision to $\mathrm{Ca}(\mathrm{OH})_{2}$ Some studies state minimal effectiveness of $\mathrm{Ca}(\mathrm{OH})_{2}$ against C.albicans (Waltimo et al. 1999, Ferguson et al. 2002), however these methods varied greatly in their examination procedure and probe preparation and also in the method of medicament application. In our study we did not place the medicament solution in direct contact with the medication outside the canal but followed the usual in vivo situation in which resistance occurs through adhesion and colonization of the dentinal surfaces and accessory canals, on the contrary to the clinical situation a higher amount on intracanal medicament is applied through the larger root canal lumen, however through sufficient amount of root filling this can be simulated. Still few studies are present about the canal disinfection with diode lasers. Gutknecht et al. 2000 and Moritz et al. 1997, could reach through the intracanal application of diode laser a reduction of streptococcus and staphylococcus to $10^{3}-10^{4} \mathrm{CFU} / \mathrm{ml}$ reached, in our study the unique laser utilization resulted in reduction to $10^{6} \mathrm{CFU} / \mathrm{ml}$ which corresponds when converted to percentage to $99 \%$. In vitro studies show many attempts to eliminate intracanal microorganisms especially E.faecalis which can reach up to $100 \%$ (Moritz et al. 1997, Gutknecht et al. 2000/2004, Schoop et al. 2006, de Souza et al. 2008) however the results obtained without previous preparation and medicaments are subjectively high. Sennhenn-Kirchner et al. investigated the effectivity of Er:YAG and 810 diode lasers against C.albicans biofilms attached to glass and titanium plates with $4 \times 20$ s irradiations and 30 s pause after each irradiation. The differences in irradiation periods, microbiological procedure and wavelengths used (810-980nm) make the direct comparison to our study invaluable. Chan et al. stated that different diode wavelengths can affgect their bactericidal activity, however this or presence of another bacterial species in the canal has a little scientific value since the bactericidal effect depends on the excessive heating and rupture of the bacterial cells and not on specific cellular elements. Even against heat resistant Bacillus stearothermophilus $\mathrm{Nd}$ :YAG laser irriadiation can be effective to achieve below $10^{2} \mathrm{CFU} / \mathrm{ml}$ reduction (Hardee et al. 1994). However pigmentation affects bacterial sensitivity to great extent due to increasing the absorption coefficient, even for resistant bacteria a methylene blue pigmentation will increase their sensitiy to diode laser irradiation (Chan et al. 2003).

\section{CONCLUSION:}

$\mathrm{CHX}$-gel and $\mathrm{Ca}(\mathrm{OH})_{2}$ had perfect effectiveness againt $\mathrm{C}$.albicans in root canals when combined with chemomechanical preparation and $\mathrm{NaOCl}$ and $\mathrm{CHX}$ irrigation, however laser disinfection showed less effectiveness and should be further investigated.

\section{SPECIAL THANKS:}

I would like to present my very grateful thanks to my dear colleagues dr. Nawar Ghazal and dr. Dimitris Papadimas at the Ruhr University of Bochum for making it possible to achieve this work, I really owe you more than I can say. 
REFERENCES (In Order Of Their Listing In The

Study):

1. Sjogren U, Figdor D, Persson S, Sundqvist G: Influence of infection at the time of root filling on the outcome of endodontic treatment of teeth with apical periodontitis. Int Endod J 1997,30:297-306.

2. Sundqvist G, Figdor D, Persson S, Sjogren U: Microbiologic analysis of teeth with failed endodontic treatment and the outcome of conservative re- treatment. Oral Surg Oral Med Oral Pathol Oral Radiol Endod 1998, 85:86-93.

3. Peters LB, Wesselink PR, Moorer WR: Penetration of bacteria in bovine root dentine in vitro. Int Endod J 2000, 33:28-36.

4. Sjogren U, Figdor D, Persson S, Sundqvist G: Influence of infection at the time of root filling on the outcome of endodontic treatment of teeth with apical periodontitis. Int Endod J 1997,30:297-306.

5. Sundqvist G: Taxonomy, ecology, and pathogenicity of the root canal flora. Oral Surg Oral Med, Oral Pathol 1994, 78:522-30.

6. Waltimo TM, Siren EK, Torkko HL, Olsen I, Haapasalo MP: Fungi in therapy-resistant apical periodontitis. Int Endod J 1997, 30:96-101.

7. Sundqvist G, Figdor D, Persson S, Sjogren U: Microbiologic analysis of teeth with failed endodontic treatment and the outcome of conservative re-treatment. Oral Surg Oral Med Oral Pathol Oral Radiol Endod 1998, 85:86-93.

8.

9. Pinheiro ET, Gomes BP, Ferraz CC, Teixeira FB, Zaia AA, Souza Filho FJ: Evaluation of root canal microorganisms isolated from teeth with endodontic failure and their antimicrobial susceptibility. Oral Microbiol Immunol 2003, 18:100-3.

10. Waltimo TM, Siren EK, Orstavik D, Haapasalo MP: Susceptibility of oral Candida species to calcium hydroxide in vitro. Int Endod J 1999, 32:94-8.

11. Siqueira JF, Jr., Rocas IN: Polymerase chain reactionbased analysis of microorganisms associated with failed endodontic treatment. Oral Surg Oral Med Oral Pathol Oral Radiol Endod 2004, 97:85-94.

12. Siren EK, Haapasalo MP, Waltimo TM, Orstavik D: In vitro antibacterial effect of calcium hydroxide combined with chlorhexidine or iodine potassium iodide on Enterococcus faecalis. Eur J Oral Sci 2004, 112:326-31.

13. Moritz A, Gutknecht N, Schoop U, Goharkhay K, Doertbudak O, Sperr W: Irradiation of infected root canals with a diode laser in vivo: results of microbiological examinations. Lasers Surg Med 1997, 21:221-6.

14. Sen BH, Safavi KE, Spangberg LS: Antifungal effects of sodium hypochlorite and chlorhexidine in root canals. $\mathrm{J}$ Endod 1999, 25:235-8.

15. Sen BH, Akdeniz BG, Denizci AA: The effect of ethylenediamine-tetraacetic acid on Candida albicans. Oral Surg Oral Med Oral Pathol Oral Radiol Endod 2000, 90:651-5.

16. Valera MC, de Moraes Rego J, Jorge AO: Effect of sodium hypochlorite and five intracanal medications on Candida albicans in root canals. J Endod 2001, 27:401-3.

17. Ferguson JW, Hatton JF, Gillespie MJ: Effectiveness of intracanal irrigants and medications against the yeast Candida albicans. J Endod 2002, 28:68-71.

18. Siqueira JF, Jr., Rocas IN, Lopes HP, Magalhaes FA, de Uzeda M: Elimination of Candida albicans infection of the radicular dentin by intracanal medications. J Endod 2003,
29:501-4

19. Menezes MM, Valera MC, Jorge AO, Koga-Ito CY, Camargo $\mathrm{CH}$, Mancini MN: In vitro evaluation of the effectiveness of irrigants and intracanal medicaments on microorganisms within root canals. Int Endod J 2004, 37:311-9.

20. Brandle $\mathrm{N}$, Zehnder $\mathrm{M}$, Weiger R, Waltimo $\mathrm{T}$ : Impact of growth conditions on susceptibility of five microbial species to alkaline stress. J Endod 2008, 34:579-82.

21. Bystrom A, Sundqvist G: Bacteriologic evaluation of the efficacy of mechanical root canal instrumentation in endodontic therapy. Scand J Dent Res 1981, 89:321-8.

22. Peters LB, Wesselink PR, Buijs JF, van Winkelhoff AJ: Viable bacteria in root dentinal tubules of teeth with apical periodontitis. J Endod 2001, 27:76-81

23. Peters LB, van Winkelhoff AJ, Buijs JF, Wesselink PR: Effects of instrumentation, irrigation and dressing with calcium hydroxide on infection in pulpless teeth with periapical bone lesions. Int Endod J 2002, 35:13-21.

24. Orstavik D, Kerekes K, Molven O: Effects of extensive apical reaming and calcium hydroxide dressing on bacterial infection during treatment of apical periodontitis: a pilot study. Int Endod J 1991, 24:1-7.

25. Weiger R, Rosendahl R, Lost C: Influence of calcium hydroxide intracanal dressings on the prognosis of teeth with endodontically induced periapical lesions. Int Endod J 2000, 33:219-26.

26. Gutknecht N, van Gogswaardt D, Conrads G, Apel C, Schubert C, Lmpert F: Diode laser irradiation and its bactericidal effect in root canal wall dentin. J Clin Laser Med Surg 2000,18:57-60.

27. Gutknecht N, Franzen R, Schippers M, Lampert F: Bactericidal effect of a 980-nm diode laser in the root canal wall dentin of bovine teeth. J Clin Laser Med Surg 2004, 22:9-13.

28. Schoop U, Kluger W, Dervisbegovic S, Goharkhay K, Wernisch J, Georgopoulos A, Sperr W, Moritz A: Innovative wavelengths in endodontic treatment. Lasers Surg Med 2006, 38:624-30.

29. de Souza EB, Cai S, Simionato MR, Lage-Marques JL: High-power diode laser in the disinfection in depth of the root canal dentin. Oral Surg Oral Med Oral Pathol Oral Radiol Endod 2008, 106:e68-72.

30. Sennhenn-Kirchner S, Schwarz P, Schliephake H, Konietschke F, Brunner E, Borg-von Zepelin M: Decontamination efficacy of erbium:yttrium-aluminiumgarnet and diode laser light on oral Candida albicans isolates of a 5-day in vitro biofilm model. Lasers Med Sci 2009, 24:313-20.

31. Hardee MW, Miserendino LJ, Kos W, Walia H: Evaluation of the antibacterial effects of intracanal Nd:YAG laser irradiation. J Endod 1994, 20:377-80.

32. Chan Y, Lai CH: Bactericidal effects of different laser wavelengths on periodontopathic germs in photodynamic therapy. Lasers Med Sci 2003, 18:51-5. 